\title{
Indole-3-acetic acid metabolism in normal and dwarf micropropagated banana plants (Musa spp. AAA)
}

\author{
Gilmar Roberto Zaffari ${ }^{1 *}$, Lázaro Eustáquio Pereira Peres², \\ Fernando Adami Tcacenco ${ }^{1}$ and Gilberto Barbante Kerbauy ${ }^{2}$
}

${ }^{1}$ Epagri, Estação Experimental de Itajaí, CP 277, CEP 88301-970, Itajaí, SC, Brasil; ${ }^{2}$ Departamento de Botânica, Universidade de São Paulo, CP 11461, CEP 05422-970, São Paulo, SP, Brasil; *Corresponding author: gzaffari@epagri.rct-sc.br

Received: 28/04/2002, Accepted: 26/11/2002

Nanism is one of the most frequent type of mutant in micropropagated banana plants from the Cavendish subgroup. The present study aimed at studying some of the hormone factors involved in this type of mutation. Rhizomes from normal and dwarf plants from the cultivar Grand Naine were incubated for $5 \mathrm{~d}$ in the presence of $\left[{ }^{3} \mathrm{H}\right]$-L-tryptophan, $\left[{ }^{3} \mathrm{H}\right]$-indole3 -acetic acid and gibberellin, to quantify the endogenous levels of indole-3-acetic acid-ester, indole-3-acetic acid-amide, free indole-3-acetic acid, and cytokinins. The endogenous levels of indole-3-acetic acid and its ester-and amide-conjugated forms were measured in normal and dwarf plants incubated for $30 \mathrm{~d}$ with gibberellin, indole-3-acetic acid, and L- and Dtryptophan. In normal plants, the use of $\left[{ }^{3} \mathrm{H}\right]$-L-tryptophan resulted in higher levels of radioactivity in the retention times corresponding to indole-3-acetic acid, indole-3-acetic acid-aspartate, indole-3-acetic acid-glycine and indole-3-acetic acid-alanine. These values were higher than those observed in dwarf plants. Higher quantities of radioactive indole-3acetic acid and of amide-forms in dwarf plants occurred in rhizomes treated with [ $\left.{ }^{3} \mathrm{H}\right]$-L-tryptophan and gibberellin simultaneously. The endogenous levels of total cytokinins were the same in both materials, while the levels of indole-3acetic acid in normal plants were 1.5 times higher than in dwarf plants. Moreover, in these ones application of tryptophan and gibberellin coincided in an increase in the levels of free indole-3-acetic acid in dwarf plants and to a decrease in the levels of indole-3-acetic acid-ester and indole-3-acetic acid-amide.

Key words: indole-3-acetic acid metabolism, growth regulators, somaclonal variation.

Metabolismo do ácido 3-indolil acético em plantas anãs e normais de bananeira micropropagada (Musa spp. AAA): O nanismo em plantas de bananeira micropropagada representa uma das formas mais comuns de alteração genética no subgrupo Cavendish. Utilizaram-se rizomas de plantas normais e anãs de bananeira cv. Grande Naine, incubados durante 5 dias na presença de $\left[{ }^{3} \mathrm{H}\right]$-L-triptofano (Trp), [ $\left.{ }^{3} \mathrm{H}\right]$-ácido 3-indolil acético e giberelina $\left(\mathrm{GA}_{3}\right)$, para o estudo da biossíntese de ácido 3-indolil acético e ácido 3-indolil acético amida e dos níveis endógenos de citocininas totais (Cks) e ácido 3indolil acético livre. Os teores endógenos de ácido 3-indolil acético e de seus conjugados éster e amida foram obtidos de plantas anãs e normais incubadas durante 30 dias na presença de GA 3 ácido 3-indolil acético e L-e D-triptofano. A aplicação de $\left[{ }^{3} \mathrm{H}\right]$-L- triptofano resultou na obtenção de quantidades mais elevadas de radioatividade nas plantas normais, no tempo de retenção coincidente com o de ácido 3-indolil acético, ácido 3-indolil acético-aspartato, ácido 3indolil acético-glicina e ácido 3-indolil acético-alanina, valores esses superiores aos observados nas plantas anãs. Verificou-se a ocorrência de maior quantidade de ácido 3-indolil acético radioativo e de forma amida nas plantas anãs nos rizomas tratados com $\left[{ }^{3} \mathrm{H}\right]$-L-triptofano e $\mathrm{GA}_{3}$ simultaneamente. Os níveis endógenos de Cks totais foram praticamente iguais em ambos os materiais, sendo o teor de ácido 3-indolil acético nas plantas normais cerca de 1,5 vez superior ao das plantas anãs. Os tratamentos com triptofano e $\mathrm{GA}_{3}$ favoreceram incremento nos níveis de ácido 3-indolil acético livre nas plantas anãs, paralelamente a uma diminuição nos teores de ácido 3-indolil acético éster e amida.

Palavras-chave: metabolismo do ácido 3-indolil acético, reguladores de crescimento, variação somaclonal. 


\section{INTRODUCTION}

The occurrence of mutants during the micropropagation of banana plants poses a serious limitation to the widespread use of this technique. Nanism is the most frequent type of mutant, occurring in up to $90 \%$ of micropropagated plants from the Cavendish subgroup (Stover, 1987; Smith, 1988; Israeli et al., 1991).

Some studies related to nanism in banana plants point to the involvement of gibberellins (Sandoval et al., 1995; Damasco et al., 1996); in other crops such as Hordeum vulgare nanism is related to low endogenous levels of indole-3-acetic acid (Inouhe et al., 1982). Most indole-3acetic acid present in plant tissues is covalently linked to other compounds, the most frequent form in legumes being the aminoacid-conjugated indole-3-acetic acid, whereas in monocots the most frequent form is represented by sugarconjugated indole-3-acetic acid (Bandurski and Schulze, 1977).

With respect to the metabolism of indole-3-acetic acid in plants, it has been shown that free indole-3-acetic acid is easily converted into esterified indole-3-acetic acid with sugar or amide-linked indole-3-acetic acid and such conjugated forms are the forms in which indole-3-acetic acid is stored in plants.

The physiological importance of indole-3-acetic acid conjugation seems to be the control of free indole-3-acetic acid in cells (Cohen and Bandurski, 1982). Previous studies with 'Grand Naine' banana plants showed that nanism was related to low sensitivity to GA and to the effect of this growth regulator in the metabolism of indole-3-acetic acid (Zaffari et al., 1998).

The present study aimed at studying the metabolism of endogenous auxin in dwarf banana plants through the quantification of the levels of free, amide-conjugated and ester-conjugated indole-3-acetic acid, as well as the measurement of the biosynthesis of indole-3-acetic acid and its amide-conjugated form.

\section{MATERIAL AND METHODS}

Plant material: The dwarf and normal plants of Musa spp. (AAA) cv. Grand Naine used in this study were obtained from in vitro culture of rhizomes in liquid MS medium (Murashige and Skoog, 1962) added with $2.5 \mathrm{mg} . \mathrm{L}^{-1}$ benzylaminopurine (BAP).
Determination of endogenous free indole-3-acetic acid and cytokinins in rhizomes: The endogenous levels of indol-3acetic acid and the cytokinins (Cks) zeatin ( $\mathrm{Z})$, zeatin riboside ([9R]Z), isopentenyladenine (iP), and isopentenyladenosine ([9R]iP), were measured using $1 \mathrm{~g}$ of fresh dwarf and normal banana rhizome tissue, which had been incubated for $5 \mathrm{~d}$ in MS liquid medium. The immunoenzymatic method was performed according to Maldiney et al. (1986) and Sotta et al. (1987) with some modifications (Peres et al., 1997). This method allowed for the determination of three hormonal classes in the same extract. Freeze-dried powdered tissues were stirred up and extracted with chilled $80 \%$ methanol containing butylhidroxytoluene $(0.18 \mathrm{mM})$ as an antioxidant for $60 \mathrm{~h}$ at $4{ }^{\circ} \mathrm{C}$ in the dark. Tritiated radiolabelled standards (IAA and ABA, specific activity $999 \mathrm{GBq} \cdot \mathrm{mmol}^{-1}$ and 2.37 TBq.mmol ${ }^{-1}$, respectively; Amersham, UK), were added to the samples for recovery estimation after purification. Tritiated IAA and ABA have been shown to perform as internal standards for Z, ZR and iP and iPA, respectively (Maldiney et al., 1986; Sotta et al., 1987). The methanolic extracts were filtered and then passed through SepPak C18 cartridges, and the eluates reduced to dryness in a vacuum with a rotary evaporator. The residues were redissolved in $500 \mu \mathrm{L}$ acid water, pH 3.0 and the hormones separated for 80 min by HPLC using a reverse-phase semi-preparative $\mu$ Bondapak $19 \mathrm{~mm} \times 300 \mathrm{~mm}$ column, at a flow rate of 5 $\mathrm{mL} \cdot \mathrm{min}^{-1}$ with a $5-50 \%$ methanol gradient in formic acid buffered to $\mathrm{pH}$ 3.0. Fractions were collected at 1-min intervals and reduced to dryness in a Speed-Vac concentrator. They were then methylated with ethereal diazomethane for IAA analysis prior to being submitted to ELISA with anti-IAA antibodies. Cytokinin measurements were carried out by ELISA with anti-[9R]Z and anti-[9R]iP antibodies. The hormone levels in each sample were measured four times and the standard deviation was calculated.

Determination of endogenous free indole-3-acetic acid, indole-3-acetic acid-amide and indole-3-acetic acid-ester in leaf sheaths: Both dwarf and normal genotypes were submitted for $30 \mathrm{~d}$ to the following treatments to determine the endogenous levels of free and bounded indole-3-acetic acid: MS (control), MS + $75 \mu \mathrm{M} \mathrm{GA}_{3}, \mathrm{MS}+50 \mu \mathrm{M}$ IAA, $\mathrm{MS}+75 \mu \mathrm{M} \mathrm{GA}_{3}+50 \mu \mathrm{M}$ IAA, MS $+500 \mu \mathrm{M} \mathrm{L}-$ tryptophan, $\mathrm{MS}+500 \mu \mathrm{M}$ L-tryptophan $+75 \mu \mathrm{M} \mathrm{GA}_{3}$, 
$\mathrm{MS}+500 \mu \mathrm{M}$ D-tryptophan, MS + 500 $\mu \mathrm{M}$ D-tryptophan $+75 \mu \mathrm{M} \mathrm{GA}_{3}$. The experiment was carried out in a completely randomized design with 10 replications and one rhizome per plot. Freeze-dried powdered tissues $(1 \mathrm{~g})$ of the leaf sheaths were stirred up and extracted with chilled $80 \%$ methanol containing butylhidroxytoluene $(0.18 \mathrm{mM})$ as an antioxidant for $60 \mathrm{~h}$ at $4{ }^{\circ} \mathrm{C}$ in darkness. Tritiated radiolabelled indole-3-acetic acid (specific activity 999 GBq.mmol ${ }^{-1}$; Amersham, UK), was added to the samples for recovery estimation after purification. The methanolic extracts were then centrifuged at $10,000 \mathrm{~g}_{\mathrm{n}}$ for $10 \mathrm{~min}$ at 4 ${ }^{\circ} \mathrm{C}$, and the supernatant filtered through SepPak C18 cartridges. After filtration, each eluate was divided into three equal amounts and reduced to dryness in a SpeedVac concentrator. For determination of ester and amide auxins, an alkaline hydrolysis was performed with two of the three samples. The alkaline hydrolysis was conducted with $1 \mathrm{M} \mathrm{NaOH}$ at room temperature for $1 \mathrm{~h}$ (ester bound conjugates) or with $7 \mathrm{M} \mathrm{NaOH}$ at $100{ }^{\circ} \mathrm{C}$ under $\mathrm{N}_{2}$ for $3 \mathrm{~h}$ (amide bound conjugates). After adjusting the $\mathrm{pH}$ to 2.5 with $\mathrm{HCl}$, the indole-3-acetic acid of all samples was extracted with ether three times. The fractions with ether were reduced to dryness in a Speed-Vac concentrator and then methylated with ethereal diazomethane. The measurements of the resulting free indole-3-acetic acid of the three amounts were carried out by ELISA with anti- indole-3-acetic acid antibodies as previously described (Peres et al., 1997). The hormone level in each sample was measured four times and the values were corrected for recovery.

Biosynthesis of free indole-3-acetic acid and indole-3acetic acid-amide in rhizomes: Indole-3-acetic acid biosynthesis in dwarf and normal banana plants was analyzed in rhizomes incubated for $5 \mathrm{~d}$ in liquid $\mathrm{MS}$ medium with the following treatments: $\mathrm{MS}+5 \mu \mathrm{Ci} \cdot \mathrm{mL}^{-1}$ [ ${ }^{3-\mathrm{H}]}$-L-tryptophan; MS $+5 \mu \mathrm{Ci} . \mathrm{mL}^{-1}\left[{ }^{3-\mathrm{H}]}\right.$-L-tryptophan $+75 \mu \mathrm{M} \mathrm{GA}_{3}$ and $\mathrm{MS}+5 \mu \mathrm{Ci} \cdot \mathrm{mL}^{-1}\left[{ }^{3-} \mathrm{H}\right]$-IAA. The cultures were kept in a growth chamber under $100 \mathrm{rpm}$ agitation and $16 \mathrm{~h}$ of light $\left(10 \mathrm{~W} \cdot \mathrm{m}^{-2}\right)$ at $28 \pm 2{ }^{\circ} \mathrm{C}$. The experiment was carried out in a completely randomized design with 3 replications, and one rhizome per plot. Before the analysis, the rhizomes were washed 5 times with milliQ water and frozen in liquid nitrogen. For the recovery estimation after purification, $1.85 \mathrm{Mbq}$ of ABA was added to the samples. After the separation in HPLC, each fraction was subjected to radioactivity counting and the incorporation picks of radioactivity were compared with the retention times for tryptophan, indole-3-acetic acid, indole-3-acetic acidaspartate (IAA-Asp), indole-3-acetic acid-glycine (IAAGly) e indole-3-acetic acid-alanine (IAA-Ala).

\section{RESULTS AND DISCUSSION}

Endogenous levels of indole-3-acetic acid and total cytokinins in dwarf and normal plants: The Cks levels were similar in both normal and mutant plants but the amounts of indole-3-acetic acid in normal plants were ca. 1.5 times higher than those found in mutants (table 1), which suggests that nanism is associated with indole-3-acetic acid metabolism. In recent studies a relationship was shown between variegated mutants and the Cks metabolism in micropropagated banana plants and in these plants the levels of chlorophylls in variegated leaves were positively correlated with the Cks levels.

Table 1. Endogenous levels of total cytokinins (Z, [9R $] Z$, iP, $[9 \mathrm{R}] \mathrm{iP})$, indole-3-acetic acid and indole-3-acetic acid/ cytokinins ratio in rhizomes from 'Grand Naine' banana genotypes after $5 \mathrm{~d}$ of incubation in Murashige and Skoog (1962) liquid culture medium.

\begin{tabular}{lccc}
\hline Genotype & IAA $^{\text {a }}$ & Cytokinins & IAA/Cytokinins \\
$($ pmol.g-1 & FW $)$ & ratio \\
\hline Normal & $118.1 \pm 28.0$ & $692.2 \pm 32.6$ & 0,17 \\
Dwarf & $78.7 \pm 30.8$ & $651.3 \pm 96.2$ & 0,12 \\
\hline
\end{tabular}

a Values are mean $\pm \operatorname{SD}(n=3)$.

Endogenous levels of free and conjugated indole-3-acetic acid in normal and dwarf plants: The presence of $\mathrm{GA}_{3}$ alone in the medium decreased the level of free indole-3acetic acid in normal plants, but did not have any effect on dwarf plants. On the contrary, indole-3-acetic acid alone in the medium depressed the amount of free indole-3-acetic acid in dwarf plants. When $\mathrm{GA}_{3}$ was added with indole-3acetic acid an increase was observed in the amount of free indole-3-acetic acid in dwarf plants, but no effect could be detected in normal plants (figure 1A).

L-tryptophan in the culture medium, with or without $\mathrm{GA}_{3}$, caused an increase in the levels of endogenous free indole-3-acetic acid in normal and dwarf plants, whereas D-tryptophan caused a decrease in those levels (figure 1A). These results corroborate the suggestion given by Baldi et al. (1991) that indole-3-acetic acid is synthesized from Ltryptophan and not from D-tryptophan, as proposed by Law 
(1987). It is also important to note that the amount of free indole-3-acetic acid present in normal plants incubated in the presence of L-tryptophan was higher than the amount found in dwarf plants under the same conditions, but incubation with L-tryptophan and $\mathrm{GA}_{3}$ at the same time caused this amount to be significantly higher in dwarf plants, compared to normal plants under the same conditions.
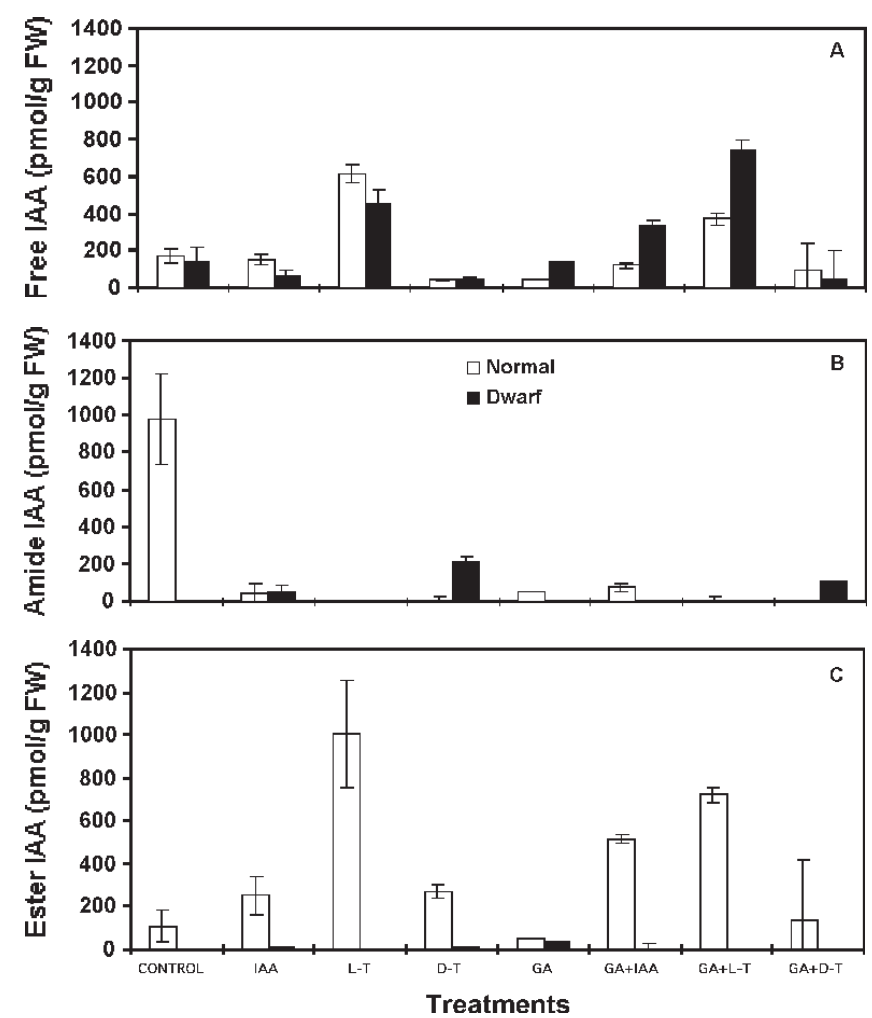

Figure 1. Endogenous levels of free indole-3-acetic acid (A), indole-3-acetic acid-amide (B) and indole-3-acetic acidester $(C)$ in pseudostems of dwarf and normal 'Grand Naine' banana plants after $30 \mathrm{~d}$ of incubation in Murashige and Skoog (1962) culture medium (MS; control), $50 \mu \mathrm{M}$ IAA + MS, $500 \mu \mathrm{M}$ L-tryptophan + MS, $500 \mu \mathrm{M}$ Dtryptophan $+\mathrm{MS}, 75 \mu \mathrm{M} \mathrm{GA}_{3}+\mathrm{MS}, 75 \mu \mathrm{M} \mathrm{GA}_{3}+50 \mu \mathrm{M}$ $\mathrm{IAA}+\mathrm{MS}, 75 \mu \mathrm{M} \mathrm{GA}_{3}+500 \mu \mathrm{M}$ L-tryptophan $+\mathrm{MS}, 75$ $\mu \mathrm{M} \mathrm{GA}_{3}+500 \mu \mathrm{M}$ D-tryptophan $+\mathrm{MS}$. Values are mean $\pm \mathrm{SD}(\mathrm{n}=10)$.

In media without growth regulators or tryptophan, only normal plants accumulated indole-3-acetic acid-amide (figure 1B). The addition of these compounds, alone or in combination, caused a severe reduction in the accumulation of indole-3-acetic acid-amide in normal plants, but indole3-acetic acid, $\mathrm{GA}_{3}$, or D-tryptophan, also caused a moderate increase in the accumulation of indole-3-acetic acid-amide in dwarf plants. Growing evidence suggests that different conjugates perform different functions in the plant. Certain conjugates, such as indole-3-acetic acidamide, can be intermediates in indole-3-acetic acid destruction (Tuominem et al., 1994). Often indole-3-acetic acid conjugates may serve as reservoirs of inactive indole3 -acetic acid that can be hydrolysed to provide the plant with active hormone. In maize, indole-3-acetic acidinositol can be transported from the kernel to the shoot, and conjugate hydrolysis, rather than de novo synthesis, supplies the developing seedling with indole-3-acetic acid (Epstein et al., 1980).

As observed with indole-3-acetic acid-amide, only normal plants accumulated indole-3-acetic acid-ester in medium without growth regulators or tryptophan. The addition of $\mathrm{GA}_{3}$ or indole-3-acetic acid alone to the medium had no significant effect, but the combination of both significantly increased the amount of indole-3-acetic acidester (figure 1C). The most marked effect was observed when L-tryptophan was added alone or in combination with $\mathrm{GA}_{3}$, whereas D-tryptophan caused only a marginal increase in the amount of indole-3-acetic acid-ester when applied alone. The broad distribution of indole-3-acetic acid-ester and indole-3-acetic acid-amide in plant tissues (Bandurski and Schulze, 1977; Sztein et al., 1995), together with the higher concentrations of these growth regulators compared with the concentration of free indole-3-acetic acid, suggest that the synthesis and the hydrolysis of these conjugated forms represent an important mechanism in the control of the auxin levels in plants (Cohen and Bandurski, 1982). The analysis of tryptophan-auxotrophic mutants with a defect in the activity of tryptophan synthase $\beta$ in maize and Arabidopsis revealed the high accumulation levels of indole-3-acetic acid in intact cells. Although Ltryptophan has been proposed to be a precursor of indole3 -acetic acid, these observations suggest the presence of a tryptophan-independent pathway, where índole or indoleglycerol might be a precursor of indole-3-acetic acid (Wright et al., 1991; Normanly et al., 1993). Recently, Dtryptophan, rather than the much more abundant $\mathrm{L}$ isomer, has been proposed to be a direct biosynthetic precursor of indole-3-acetic acid based on evidence of gibberellin enhanced racemization of L-tryptophan to D-tryptophan, which could then be transaminated to indolepyruvic acid (Law 1987; McQueen-Mason and Hamilton, 1989). Lantican and Muir (1969) have reported that $\mathrm{GA}_{3}$ does not decrease indole-3-acetic acid-aspartate synthesis in pea 
stems. In the long-standing argument concerning a possible role for auxin in the mediation of GA-induced elongation, it is often noted that exogenous auxin fails to increase growth to an extent comparable to that obtained with exogenous GA. However, such a proposed GA-induced increase in indole-3-acetic acid biosynthesis coupled with reduced conjugation might be relevant, especially given that exogenous auxins induce conjugation (inactivation) of indole-3-acetic acid (Venis, 1972).

However, it was observed in a previous study that the enzymatic degradation of free indole-3-acetic acid in dwarf banana plants was ca. 1.5 times higher than that observed both in rhizomes and leaves in normal plants (Zaffari et al., 2000). This observation suggests that the control of the endogenous level of indole-3-acetic acid through enzymatic degradation may be a mechanism to compensate for the low conjugation capacity found in dwarf mutants (figures $1 \mathrm{~B}$ and $1 \mathrm{C}$ ).

Biosynthesis of auxin in normal and dwarf plants: The retention times (RT) for the studied compounds were: tryptophan $=32.19 \mathrm{~min}$; indole- 3 -acetic acid-asp $=40.50$ $\mathrm{min}$; indole-3-acetic acid-gly $=41.45 \mathrm{~min}$; indole-3-acetic acid-ala $=45.92 \mathrm{~min}$; and indole- 3 -acetic acid $=51.20 \mathrm{~min}$ (figure 2). The patterns of indole-3-acetic acid-amide retention times are relatively low when compared to the patterns for free indole-3-acetic acid. This small interaction with the stationary apolar phase is probably due to the higher polarity of aminoacids. The treatment with $\left[{ }^{3} \mathrm{H}\right]-\mathrm{L}-$ tryptophan led to the incorporation of radioactivity in the RT corresponding to indole-3-acetic acid-asp, indole-3acetic acid-gly, indole-3-acetic acid-ala and indole-3-acetic acid in the rhizomes of normal and dwarf plants, the incorporation in the RT for indole-3-acetic acid-gly being the most expressive in both genotypes (figure $3 \mathrm{~A}$ ). In general the incorporation of radioactivity in normal plants was markedly superior to that observed in mutant plants (figure 3A), which suggests that the genotypes studied presented differences in their capacity for indole-3-acetic acid biosynthesis. In addition, this biosynthesis seems to be at least partially dependent upon tryptophan, with an expressive fraction of the $\left[{ }^{3} \mathrm{H}\right]$ - indole-3-acetic acid formed being incorporated in substances with RT equivalent to those found in some aminoacid-conjugated forms. An inverse effect in indole-3-acetic acid biosynthesis and conjugation was observed between the two genotypes when incubated with $\left[{ }^{3} \mathrm{H}\right]$-L-tryptophan $+\mathrm{GA}_{3}$, since there was more incorporation in the dwarf mutant (figure $3 \mathrm{~B}$ ), which is in agreement with the data from figure 1. Incubation with $\left[{ }^{3} \mathrm{H}\right]$ - indole-3-acetic acid led to an accumulation of radioactivity in the RT equivalent to that of free indole-3acetic acid, particularly in normal plants (figure 3C).

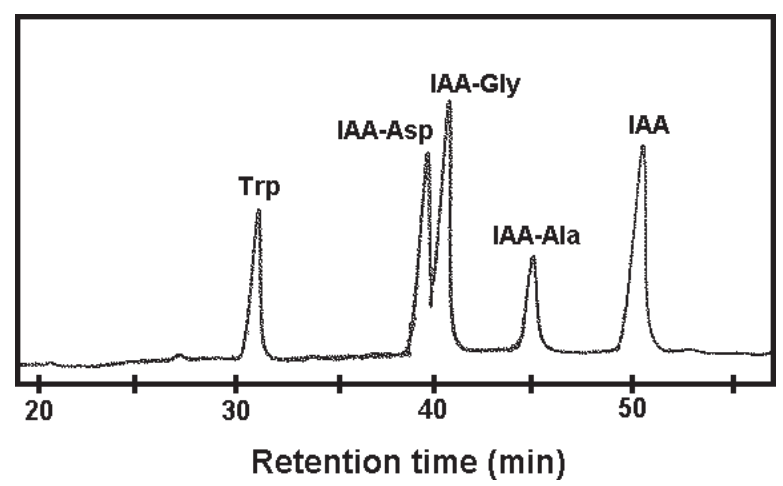

Figure 2. Radioactive patterns of tryptophan, indole-3-acetic acid-asp, indole-3-acetic acid-gly, indole-3-acetic acid-ala and indole-3-acetic acid in HPLC. CPM = counts per min.

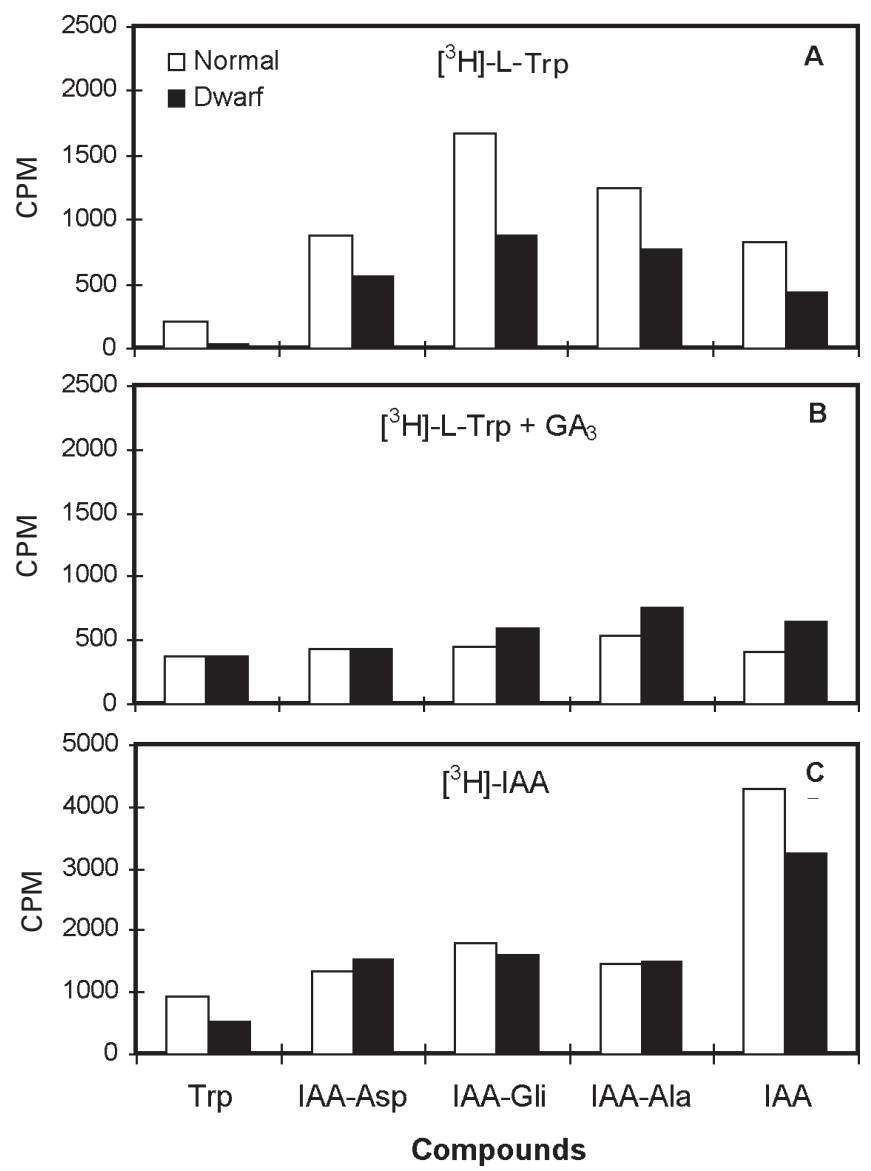

Figure 3. Radioactivity distribution in HPLC methanolic extracts, from rhizomes of 'Grand Naine' banana plants after $5 \mathrm{~d}$ of incubation with (A) $\mathrm{MS}+5 \mu \mathrm{Ci} \mathrm{mL}^{-1}\left[{ }^{3-\mathrm{H}}\right]$-Ltryptophan, (B) $\mathrm{MS}+5 \mu \mathrm{Ci} \cdot \mathrm{mL}^{-1}\left[{ }^{3-\mathrm{H}}\right]$-L-tryptophan +75 $\mu \mathrm{M} \mathrm{GA}_{3}$ and $(\mathrm{C}) \mathrm{MS}+5 \mu \mathrm{Ci} \cdot \mathrm{mL}^{-1}\left[{ }^{3-} \mathrm{H}\right]$-indole-3-acetic acid. $\mathrm{CPM}=$ counts per $\min$. 
Pseudostems from both genotypes presented low endogenous levels of indole-3-acetic acid-amide $30 \mathrm{~d}$ after rhizome incubation unlike rhizomes incubated for $5 \mathrm{~d}$ in the presence of L-tryptophan, L-tryptophan $+\mathrm{GA}_{3}$ and indole-3-acetic acid (figures 3A, 3B and 3C, respectively). These results indicate that the amide conjugates in rhizomes could accumulate in pseudostems as free and ester forms of indole-3-acetic acid in normal plants, and as free form in dwarf banana plants (figures $1 \mathrm{~A}$ and $1 \mathrm{C}$ ). These results show the interaction between exogenous $\mathrm{GA}_{3}$ and indole-3-acetic acid metabolism in both banana genotypes. Although the occurrence of interactions between the metabolism of endogenous gibberellins and indole-3-acetic acid has already been demonstrated (Tsurusaki et al., 1990; Zaffari et al., 2000), there is little information on the regulatory mechanisms involved.

This study suggested that dwarfism in banana plants is related not only with low endogenous levels of gibberellins, as proposed by Sandoval et al. (1995) and Damasco et al. (1996), but also with a decrease in the endogenous levels of indole-3-acetic acid. A putative interaction between the metabolism of gibberellin and indole-3-acetic acid may occur in this mutant type. Although little is known about the interaction between the metabolism of these two growth regulators, the present results corroborate previous reports in the literature pointing to the involvement of these growth regulators on the control of cell division and growth in leaves, sheaths and stems of normal and dwarf banana plants.

Acknowledgements: The authors wish to thank Fundação de Amparo à Pesquisa do Estado de São Paulo (FAPESP) and Conselho Nacional de Desenvolvimento Cientifico e Tecnológico (CNPq) for financial support, and Dr. B. Sotta (Université Paris VI) for the donation of the antibodies and conjugates for ELISA.

\section{REFERENCES}

Baldi BG, Maher BR, Slovin JP, Cohen JD (1991) Stable isotope labelling, in vivo, of D- and L-tryptophan pools in Lemma gibba and the low incorporation of label into IAA. Plant Physiol. 95:1203-1208.

Bandurski RS, Schulze A (1977) Concentration of indole-3acetic acid and its derivatives in plants. Plant Physiol. 60:211-213.
Cohen JD, Bandurski RS (1982) Chemistry and physiology of the bound auxins. Annu. Rev. Plant Physiol. 33:403-430.

Damasco OP, Godwin ID, Smith MK, Adkins SW (1996) Gibberellic acid detection of dwarf off-types in micropropagated Cavendish bananas. Aust. J. Exp. Agric. 36:237-241.

Epstein E, Cohen JD, Bandurski RS (1980) Concentration and metabolic turnover of indoles in germinating kernels of Zea mays L. Plant Physiol. 65:415-421.

Inouhe M, Sakurai N, Kuraishi S (1982) Growth regulation of dark-grown dwarf barley coleoptile by the endogenous IAA content. Plant Cell Physiol. 23:689-698.

Israeli Y, Reuveni O, Lahav E (1991) Qualitative aspects of somaclonal variations in banana propagated by in vitro techniques. Sci. Hortic. 48:71-88.

Lantican BP, Muir RM (1967) Isolation and properties of the enzyme system forming indoleacetic acid. Plant Physiol. 42:1158-1160.

Law DM (1987) Gibberellin-enhanced indole-3-acetic acid biosynthesis: D-Tryptophan as the precursor of indole3-acetic acid. Plant Physiol. 70:626-632.

Maldiney R, Leroux B, Sabbagh I, Sotta B, Sossountzov L, Miginiac E (1986) A biotin-avidine enzyme immunoassay to quantify three phytohormones: auxin, abscisic acid and zeatin-riboside. J. Immunol. Meth. 90:151-158.

McQueen-Mason S, Hamilton RH (1989) The biosynthesis of indole-3-acetic acid from D-tryptophan in Alaska pea plastids. Plant Cell Physiol. 30:999-1005.

Murashige T, Skoog F (1962) A revised medium for rapid growth and bioassays with tobacco tissue culture. Physiol. Plant. 15:473-497.

Normanly J, Cohen JD, Fink GR (1993) Arabidopsis thaliana auxotrophs reveal a tryptophan-independent biosynthetic pathway for indole-3-acetic acid. Proc. Natl. Acad. Sci. USA 90:10355-10359.

Peres LEP, Mercier H, Kerbauy GB, Zaffari GR (1997) Níveis endógenos de AIA, citocininas e ABA em uma orquídea acaule e uma bromélia sem raiz, determinados por HPLC e ELISA. Rev. Bras. Fis. Veg. 9:169-176.

Sandoval J, Kerbellec F, Côte F, Doumas P (1995) Distribution of endogenous gibberellins in dwarf and giant off-types banana (Musa AAA, cv. "Grand nain") plants from in vitro propagation. Plant Growth Regul. 17:219-224.

Smith MK (1988) A review of factors influencing the genetic stability of micropropagated bananas. Fruits 43:210-223.

Sotta B, Pilate G, Pelese F, Sabbagh I, Bonnet M, Maldiney R (1987) An avidine biotin solid phase ELISA for fentomole isopentenyladenine and isopentenyladenosine measurements in HPLC purified plant extracts. Plant Physiol. 84:571-573. 
Stover RH (1987) Somaclonal variation in Grande Naine and Saba bananas in the nursery and field. In: Persley GJ, Delanghe EA (eds), Proceedings of the International Workshop Banana and Plantain Breeding Strategies. Cairns, Australia, pp.136-139.

Sztein AE, Cohen JD, Slovin JP, Cooke TJ (1995) Auxin metabolism in representative land plants. Am. J. Bot. 82:1514-1521.

Tsurusaki K, Watanabe S, Sakurai N, Kuraishi S (1990) Conversion of D-tryptophan to indole-3-acetic acid in coleoptiles of a normal and a semi-dwarf barley (Hordeum vulgare) strain. Physiol. Plant. 79:221-225.

Tuominem H, Ostin A, Sandberg G, Sundberg B (1994) A novel metabolic pathway for indole-e-acetic acid in apical shoots of Populus tremula (L.) X Populus tremuloides (Michx.). Plant Physiol. 106:1511-1520.
Wright AD, Sampson MB, Neuffer MG, Michalczuk L Slovin JP, Cohen JD (1991) Indole-3-acetic acid biosynthesis in the mutant maize orange pericarp, a tryptophan auxotroph. Science 254:998-1000.

Venis MA(1972) Auxin-induced conjugation systems in peas. Plant Physiol. 49:24-27.

Zaffari GR, Peres LEP, Kerbauy GB (1998) Endogenous levels of cytokinins, IAA, ABA and pigments in variegated somaclones of micropropagated banana leaves. J. Plant Growth Regul. 17:59-61.

Zaffari GR, Peres LEP, Suzuki RM, Kerbauy GB (2000) Offtype micropropagated banana plants: endogenous levels of auxin and cytokinins and IAA metabolism. Acta Hortic. 520:219-228. 